\title{
Study on Characteristics and Application of Modern Green Building Materials
}

\author{
Fangfang Yang \\ The Department of Architecture and Engineering Qinhuangdao College, Northeast Petroleum University, Qinhuangdao, \\ 066004, China
}

\begin{abstract}
Modern green building materials have the virtues of energy saving and environmental protection. They are the development direction of modern building materials. This paper introduces several modern green building materials, including concrete materials, green wood, insulation materials and green waterproof material. The material characteristics of them are analyzed detailed. Some application study cases are shown to demonstrate the good prospects of green building materials.
\end{abstract}

Keywords-green material, environmental protection, green building

\section{INTRODUCTION}

Modern green building materials refers to a building material with excellent quality, performance and environmental coordination. Its performance is better than that of the product must meet the national standards in its production process must be used in compliance with the state provisions to allow the use of raw and fuel materials $\mathrm{R}$ and minimize the use of natural raw materials of $\mathrm{F}$ and exhaust emissions, waste liquid and waste residue, dust, dust quantity, composition of reach or more stringent than the national permitted emission standards in the use process reached or exceeded the national standard provisions of the nontoxic and harmless in $\mathrm{K}$ and combined into a building department will not cause pollution and potential safety hazard the waste after use on the human body, the atmosphere, water, soil and other causing less pollution and to a certain extent, can recycling and repeated the use of them[1].

\section{MODERN GREEN CONCRETE}

Concrete is the main building material of modern architecture, so the development of green concrete material is crucial for green building.

\section{A. High Performance Concrete Material}

High performance concrete is a kind of high new technology of concrete; improve the performance of conventional concrete based on the large scale, good durability, applicability, work, various mechanical properties, volume stability and economic rationality properties. High performance concrete in addition to the use of high quality cement, water, aggregate, it is necessary to adopt the low water binder ratio by adding a sufficient number of fine mineral admixture and high efficient additives, the use of modern concrete technology, highquality raw materials, manufactured in the quality control of properly under the.

\section{B. The Use of Green Concrete Waste Concrete Production}

Now a large number of studies show that, the waste concrete can be used as recycled concrete aggregate; can replace part of high-quality limestone for cement production. The waste concrete washing, crushing, grading and according to the certain proportion can be obtained after aggregate called "recycled aggregate", will be recycled aggregate as a part or the whole of the concrete aggregates become "recycled concrete". Experiments show that the compressive strength of recycled concrete can meet the design requirements, other index of mechanical performance and durability index and ordinary concrete, with more water than ordinary concrete[2].

\section{The Aerated Concrete}

As shown in Fig.1, autoclaved aerated concrete (one) is quartz sand as the foundation, with cement and lime as cementations material, gypsum as hardening agent, powder as foaming agent, by high temperature high pressure maintenance after the formation of the porous material.

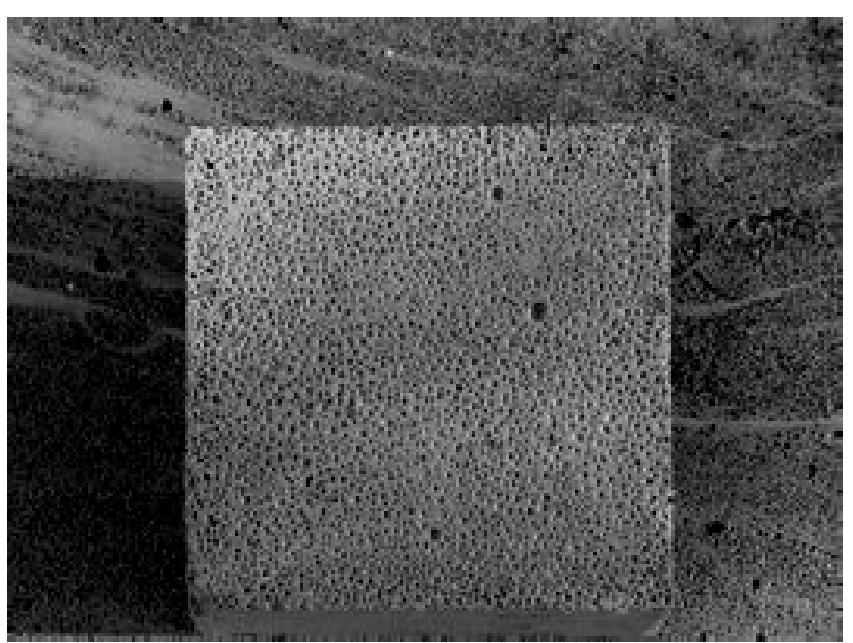

Fig. 1. Porous aerated concrete

\section{Synthetic Fibre Reinforced Concrete}

Synthetic fibre reinforced concrete has been widely used. To strengthen the concrete early tensile strength, prevent the intrinsic micro crack early by subsidence, hydration heat, shrinkage and produce, reduce the surface crack and crack width have significant effects of anti shock performance of reinforced concrete impervious performance, anti-wear and enhance structural integrity[3]. 
The porous performs planting concrete. Planting concrete continuous space, the gap part, filling inorganic culture soil, using special technology of fertilizer and seeds mixed growth base material, construction, seed germination and growth of water required, except by the growth in base material stored in the rain, but also can absorb the following basic planting concrete soil moisture in the culture, without additional watering, so as to achieve a green, have can prevent the structures of surface contamination and erosion. Planting concrete also has the permeability performance is quite good, the rain water to the underground infiltration, so can replenish groundwater resources, it can reduce the pressure of municipal drainage of rainwater pipeline.

\section{MODERN GREEN WOOD}

Wood has become a modern green building materials highlights the progress of technology, with the emergence of many new forms of use.

\section{A. The Colour of Wood}

Using the dyeing technology advanced, so that no native trees in color penetration in the wood tissue, forming the color of wood. It can be divided into two kinds, a kind of congenital colored wood. That growth in various periods of trees, tree root ministry to irrigate or on parts of the trunk perfusion harmless water soluble color nutrient solution, color along the inner catheter transmission trees and is absorbed, coloring, color wood formation. Another is the day after tomorrow colored wood. That is, choose among the texture of the wood slice, first decolonization, and then stained with the appropriate colour[4]. Colour wood suitable for furniture, ceilings, walls and other large area of surface decoration, do not have emotional appeal.

\section{B. Ceramic Wood}

Soak the wood chemical solution with barium ions barium ion diffusion, penetration into the wood tissues and cells, with certain process the wood into wood, porcelain. The jet flame test, no flame, almost smokeless, produced only low carbonization. The super fire retardant wood for the hall of furniture and decoration is suitable for the interior of the vehicle especially large-scale public places of entertainment of interior decoration.

\section{Plastic wood}

The vinyl resin is injected to the internal formation of wood, plastic wood. Plasticizing wood has a strong compression, bending, shear and comprehensive strength, greatly reduced such as split with wear defects, hardness and strength of strong. Plastic wood floor will be widely used in decoration engineering, as shown in Fig.2.

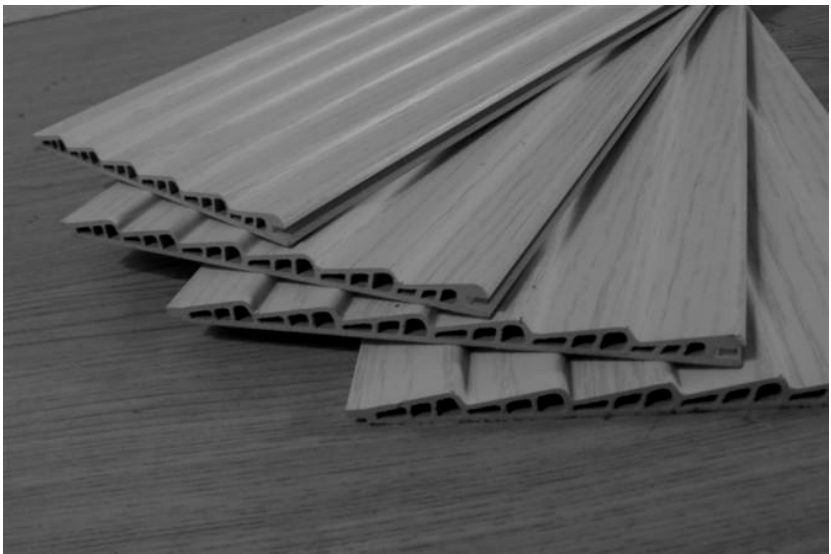

Fig.2. Floor made of plastic wood

\section{Hydrophobic Wood}

Hydrophobic wood in the moist air expansion rate only half of ordinary wood, water absorption rate of only ordinary wood $1 / 5$, principle of hydrophobic material is the active hydroxyl hydrophilic wood into acetyl hydrophobic. Wood can be used as hydrophobic Bath Interior decoration, furniture etc. in the desktop and the ship, but also can be used for outdoor decoration.

\section{MODERn GREen Thermal INSUlAtion MATERIAL}

Insulation materials according to their differences in the use of part of the retaining structure, can be divided into internal, external insulation materials; thermal insulation material for plate shape, slurry according to the different of the state. The main performance index of insulation materials: thermal conductivity, apparent density, compressive strength, dimensional change rate, water absorption rate, water vapor permeability, bond strength, oxygen index. Plate shaped heat insulation is material, can be used for internal, external thermal insulation engineering; characterized by its shape, has convenient use, can ensure the requirements of thermal insulation layer thickness, stable performance.

Good plate shape insulation materials: expanded polystyrene board extruded polystyrene board of different materials, rock wool board, and glass wool board. There are two types of paste like material, drying curing type in cementations materials and mainly to the evaporation of water based.

The main ingredient is dominated by polystyrene particles of various materials, mineral fiber, silicate, light through a certain production process of composite insulation materials. In addition, insulation material also includes other commonly used materials: porous materials, such as hollow brick, aerated concrete block; insulating aluminum window frames, using thermal conductivity is far below the parting strip aluminum will aluminum partition, the formation of aluminum alloy door and window section bar insulation - aluminum - aluminum composition; LOW E low radiant heat glass, hollow glass, laminated glass etc. 


\section{MOdERn GREen WATERPROOF MATERIAL}

Modern green building waterproof material not only has the function of waterproof basic also has other functions such as thermal insulation, decontamination, and in the production is relatively small impact on the environment in the course of use.

\section{A. Polymer Cement Waterproof Coating}

Polymer cement waterproof coating with cement and acrylic acid (emulsion or other) aqueous polymer as main raw materials and adding other additives prepared twocomponent waterborne architectural waterproof coating. The two components in the field of mixing into a uniform, fine slurry, brushing or spraying on the surface of the basal body, formed by solidification waterproof coating flexibility, high strength. The coating has not only high strength cement materials, performance easily with the damp surface bonding, both polymer film elasticity, has the advantages of good waterproof, especially with water as the carrier, to overcome the asphalt, tar, organic solvent type waterproofing material is easy to cause environmental pollution shortcomings, is a non-toxic harmless, wet table operation, simple construction of the new green waterproof material. It not only applies to all kinds of waterproof engineering, but also can be used for repairing, interface treatment, protection of concrete structure engineering, decoration, sealing etc.

\section{B. Permeable Crystallization Type Waterproof Material}

Permeable crystallization type waterproof material refers to the chemical active materials containing penetration to concrete interior, forming crystalline insoluble in water body in the concrete, block the pores, so that the waterproof material concrete dense. Its waterproof is properties and excellent.

\section{Impervious Plastic Repair Agent}

Impervious plastic repair agent is capable of rapidly to prevent new building chemical paint house leakage. The waste plastic woven bag, plastic film, foam and other plastic scrap as raw material, adding to the reasonable plasticizer, curing agent, using low pressure cold soluble reaction produced, with quick plasticization, quick drying, good smoothness, sealing, adhesive, waterproof, elasticplastic and thermal, cold resistance, corrosion resistance, anti aging characteristics. Its production process is not only less equipment investment, energy saving, but also completely eliminates the pollution of waste plastics on the environment.

\section{CONCLUSIONS}

In short, modern green building materials with the necessity of its development is the development direction of modern building materials, increasing attention from all walks of life. The status quo and the development speed of modern green building materials are showing good momentum, that it will have very good prospects for development, green building materials will have a new type and high quality more and more have been developed and used.

\section{REFERENCES}

[1] Shi, Y. J. Research on the problems of environmental protection in construction. Technology of Wind, 23(9), pp.154-155, 2013.

[2] Cai, J. L. Thought and research on the city building energy efficiency in China. Journal of North China Institute of Science and Technology, 27(10), pp. 26-28, 2005.

[3] Cao, L. X. The development trend of green building design. China New Technology and New Products, 30(8), pp.172-173, 2010.

[4] Gao, J. C. Some thoughts of building energy saving. City Development, 11(7), pp.15-16, 2005. 